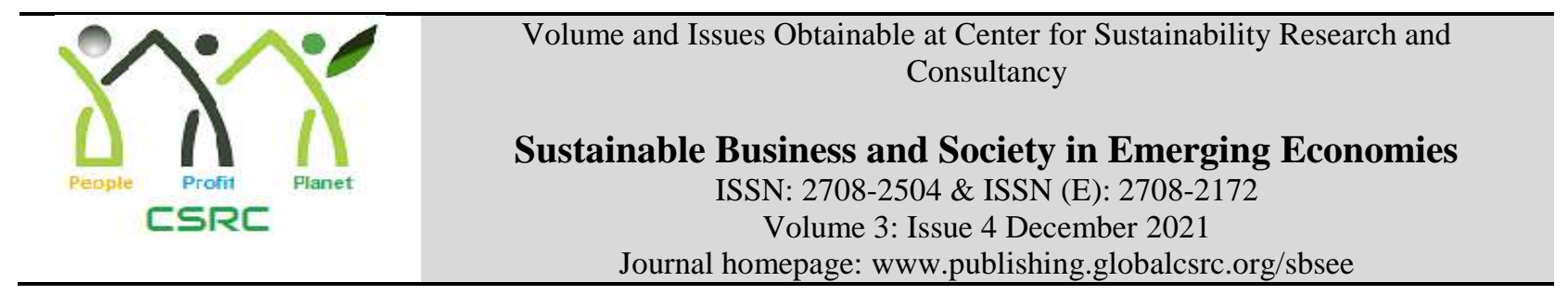

\title{
Determinants of Employees' Openness to Change: Insights from Service and Manufacturing Sectors of Pakistan
}

Umaima Mahmood Qamar Saddiqui, IB\&M, University of Engineering and Technology, Lahore, Pakistan

Kanwal Shaheen, Department of Management Sciences, Government College Women University, Faisalabad, Pakistan

*Qamar Ali, Lyallpur Business School, Government College University Faisalabad, Faisalabad, Pakistan

*Corresponding author's email address: qamarali@gcuf.edu.pk

ARTICLE DETAILS

History

Revised format: Nov 2021

Available Online: Dec 2021

\section{Keywords}

Authentic Leadership,

Symmetrical Communication,

Organizational Trust,

Openness to Change

JEL Classification

L6, L69

\section{ABSTRACT}

Purpose: The volatile, uncertain, complex, and ambiguous (VUCA) world environment has forced organizational leaders more than ever to adopt new leadership styles in order to bring sustainable changes. This study tends to examine the impact of authentic leadership and symmetrical communication on employees' openness to change. In doing so, the study also illustrates the mediating character of organizational trust.

Design/Methodology/Approach: A self-administrated questionnaire based on a Five-point Likert scale was used to record the perceptions of top-level and middle-level managers from the services and manufacturing sectors of Pakistan. Data were analyzed through Partial least squares structural equation modelling (PLS-SEM) technique in SmartPLS version 3.2.9.

Findings: Results of this study reveal that authentic leadership promotes organizational trust among the individuals at the workplace, which further strengthens openness to change. Similarly, symmetrical communication also promotes corporate trust among workers. Interestingly organizational trust has been found a mediating phenomenon in this case.

Implications/Originality/Value: The study adds important insights into the literature and practically provides guidelines to tackle the change management process in organizations. The study implies that in order to perpetuate employees' susceptibility to change, an organization needs to promote authentic leadership.

(C) 2021 The authors, under a Creative Commons AttributionNonCommercial- 4.0

Recommended citation: Saddiqui, Q. M. U., Shaheen, K. and Ali, Q. (2021). Determinants of Employees' Openness to Change: Insights from Service and Manufacturing Sectors of Pakistan. Sustainable Business and Society in Emerging Economies, 3(4), 497-508 


\section{Introduction}

Worldwide organizations constantly undergo rapid changes in volatile, uncertain, complex, and ambiguous (VUCA) environments (Pearse, 2017). Organizations experience severe challenges and troubles in the change management processes. In this perspective, employees' openness and readiness to change are vital factors for organizational success, requiring organizations to adopt new leadership approaches (George et al., 2007; Yue et al., 2019). Organizations want leaders with reason, values, and truthfulness to create strong cultures. In every society, honesty and genuineness are considered as most essential community morals. Kouzes and Posner (2006) found that the main determinant of successful leadership is to treat subordinates with authenticity. Loyalty and authenticity enhance an enterprise's compassionate environment and achieve long-lasting results. The authentic leadership approach has been increasingly adopted in research and practice (Avolio et al., 2004; Alilyyani et al., 2018). Although not without criticism (Alvesson, 2019), authentic leadership is recognized as the origin of progressive forms of leadership. This approach positively addresses managerial challenges, thereby drawing positive organizational insights. The positive corporate atmosphere refers to great self-awareness and moral authenticity (Walumbwa et al., 2008). Authentic leaders have a self-concept, promote openness, know their positive and negative aspects, and above all, their conduct rests on high ethical values (Leroy et al., 2012). Organizations implement changes to improve effectiveness and adapt to the environment (Nielsen et al., 2010). Employees' behaviors significantly influence the change process and organizational outcomes (Nielsen \& Randall, 2013). Effective communication plays an essential role in bringing positive attitudes among employees (Gray \& Laidlaw, 2004).

A plethora of research indicates that organizational trust is linked with performance and success (Currall \& Epstein, 2003), and reputation (Yang, 2007). Trust is also connected with individual-level outcomes such as citizenship behavior (Duffy \& Lilly, 2013) and job satisfaction (Yang, 2014). On the other hand, change within an organization ensures employees that they are not safe and feel a sense of insecurity (Allen et al., 2007). However, employees' trust built as a result of leadership and internal communication can influence the perception of individuals, and hence they can reduce their hesitation and psychological pressure. This state of affairs leads towards acceptance of the change (Rousseau \& Tijoriwala, 1999).

The VUCA world has forced organizations to be vigilant and bring sustainable changes to survive (Johansson \& Heide, 2008; Oberoi et al., 2021). However, all these efforts to initiate strategic change do not result in fruitful outcomes due to uncertainties (Corley \& Gioia, 2004), and hence nearly 70\% of change initiatives fail. Failed attempts to bring organizational change result in wastage of time and money. Other drastic consequences also emerge, such as reduced self-confidence and commitment. This lower level of self-confidence and commitment hampers employee efficiency and performance, and the organization as a result suffers. Further, this also drives individuals to quit the organization (Chawla \& Kevin Kelloway, 2004), thereby increasing the burden on leaders' shoulders, who as a result become more cautious in implementing change within corporate circuits (Pawar \& Eastman, 1997). It raises the need for organizations to adopt new leadership approaches which can sustain the challenges in the dynamic world (George et al., 2007). Another significant factor emerging from previous research is strategic internal communication, which has the potential to hamper change processes in organizations; because change initiatives can fail if not communicated properly to the employees (Elving, 2005).

This study examines the impact of authentic leadership and symmetrical communication on employees' openness to change, thereby exploring the intervening role of organizational trust. Previous research lacks studies on the relationship between authentic leadership and employees' susceptibility to change (Yue et al., 2019). Moreover, the role of symmetrical communication in this relationship is also yet to be rigorously tested. The findings of this study extend the current knowledge on authentic leadership by exploring the intervening role of organizational trust in employees' openness to change, thereby trying to neutralize the criticism on the overwhelmingly positive notion of authentic leadership. It adds important insights into the literature, and practically provides guidelines to tackle openness to change, confidence, and symmetrical communication. 


\section{Operational Definition of Variables}

Cameron and Dutton (2003) describe authentic leadership as a process of using positive psychological capacities, resulting in greater self-awareness and self-directed positive behaviors on the part of leaders and followers. On the other hand, symmetrical internal communication is based upon employee empowerment and participation in decision-making processes. It is often associated with a participative organizational culture, and an organic structure (Grunig \& Grunig, 2011). Openness to change can be a single attribute based on the features of flexibility and originality (Ertürk, 2008). It is associated with two parts. One is linked with positive affect towards change outcomes (Grau, 1994). At the same time, the optimistic effect is encompassed in warm attitudes towards change and willingness to accept change (Augustsson et al., 2017). Organizational trust was defined as the willingness of a party to be vulnerable to the actions of another party (Schoorman et al., 2007) and the decision to rely on another party under a condition of risk (Currall \& Epstein, 2003). This definition denotes two basic parts of relational trust: dependency and vulnerability (Rawlins, 2008).

\section{Theory and Hypotheses Development}

This study is grounded in Social Exchange Theory (SET) (Blau, 1964). SET focuses on the employeremployee exchange relationships (Whitener et al., 1998). When the followers perceive that their leaders treat them fairly and act morally, they represent positive behaviors and attitudes. Authentic leadership and symmetrical communication are organizational socio-emotional resources related to employees' positive behaviors and attitudes. When employees receive benefits from organizational resources, they have to repay the organization. SET focuses on barter and remuneration between the employer and the employee. When the employer gives highly valuable socioeconomic and socio-emotional benefits to its employees (Saks, 2006), the employees in return try to reciprocate the favor. If the supervisors treat employees fairly, make ethical decisions, and deal with employees authentically, employees are more willing to implement changes.

Majeed et al. (2021) categorize organizational trust into three facets; trust in the organization, trust in coworkers, and trust in the supervisor. The level of commitment and satisfaction increases with trust, strengthening the link between the leader and the followers. Authentic leadership brings positive change in employees' perception of trust towards the organization, colleagues, and supervisors. Moreover, organizational trust has a positive relationship with citizenship behavior. The relationship between authentic leadership and citizenship behavior is also mediated by organization trust. Relational transparency is vital in developing trust when it has disintegrated, particularly in reestablishing trust (Basit, 2020). Bakari et al. (2019) attempted to discover the link between authentic leadership and employee commitment. Authentic leadership is connected to commitment to change and brings positive change in employees' commitment when their organization undergoes change or rebuilding process. One might say that authentic leadership influences individual and organizational change thinking about the relational transparency aspect (Kilic, 2021; Ilyas, 2020). Yue et al. (2019) studied the impact of transformational leadership and transparent organizational communication on an individual's perception of trust during an organizational change event. In a study of openness to changes in Turkish firms, Ertürk (2008) discovered that the relationship between openness to change and managerial communication correspond to trust in one's supervisor. On the other hand, Kang and Sung (2017) reaffirm that symmetrical internal communication of an organization has the potency to affect its individuals to shape various behaviors and attitudes in favor of their organizations.

\section{Hypotheses}

H1. There is a positive association between authentic leadership and organizational trust.

\section{H2: Symmetrical Communication has a positive relationship with organization trust.}

H3: Organizational trust has a significant link with openness to change. 
H4: Authentic leadership has a positive relationship with openness to change.

H5: Symmetrical communication has a positive relationship with openness to change.

H6: Organizational trust mediates the relationship of authentic leadership and openness to change.

H7: Organizational trust mediates the relationship of symmetrical communications and openness to change.

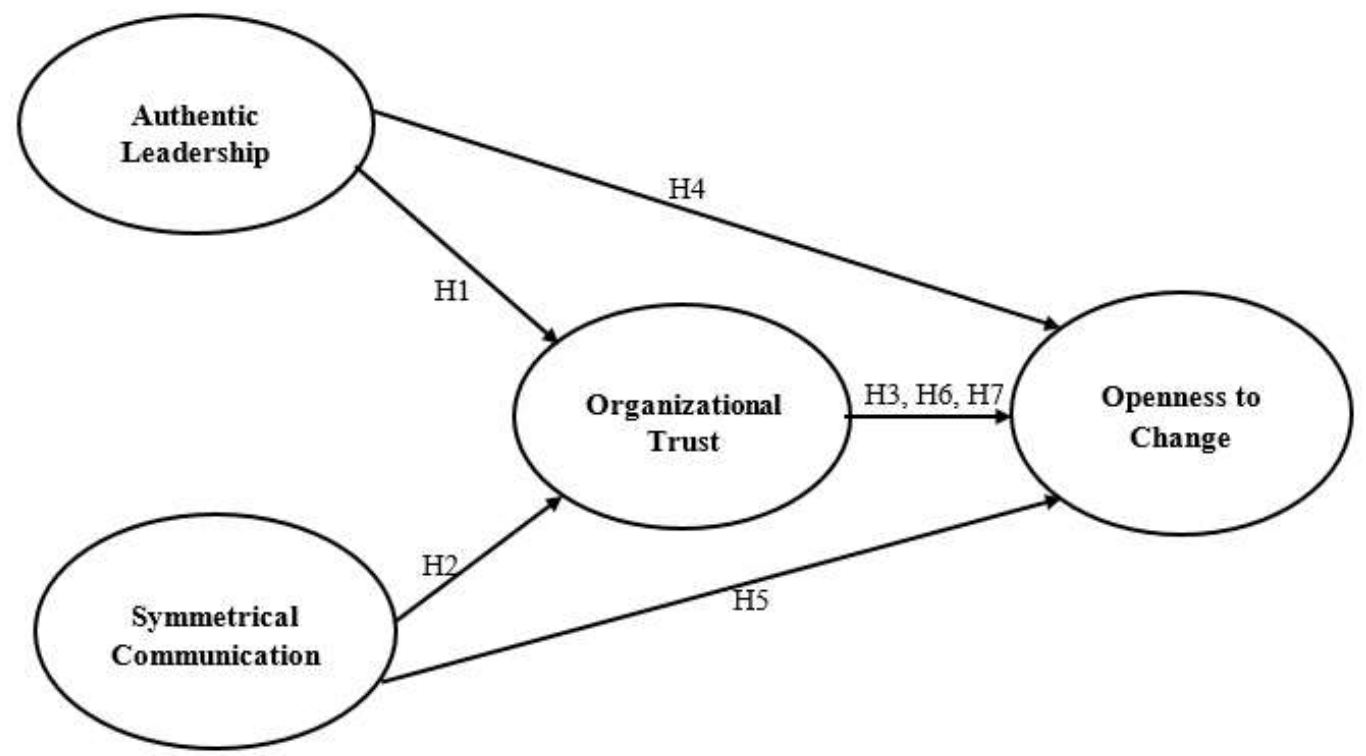

Figure 1: Study Framework

\section{Methodology}

\section{Participants and Procedure}

This study examines the impact of authentic leadership and symmetrical communication on employees' openness to change. Further, the study also incorporated organizational trust as an intervening phenomenon. The cross-sectional survey design was used with top-level and middle-level managers from different organizations of services and manufacturing sectors. A self-administrated questionnaire based on a Five-point Likert scale was used to record respondents' perceptions regarding leadership style, symmetrical communication, employees' openness to change, and organizational trust. For this purpose, established literature has been consulted, and a questionnaire is designed based on wellestablished scales. The unit of analysis was individuals.

As a popular rule of thumb for robust PLS-SEM estimations, Barclay et al. (1995) suggested that a minimum sample size of ten times should be against a maximum number of paths aiming at any construct within the model. To collect the responses, a convenience sampling technique was used. We analyzed the data with the help of descriptive and inferential statistics. Statistical Package for Social Sciences (SPSS) and Smart PLS 3.2.9 were used for this purpose. 
Table 1 Demographic Data of Respondents $(n=256)$

\begin{tabular}{|l|l|l|}
\hline Categories & Frequency & Percentage \\
\hline Age & & \\
25 & 62 & 24.2 \\
$26-30$ & 68 & 26.6 \\
$31-35$ & 69 & 27.0 \\
$36-40$ & 28 & 10.9 \\
$41-45$ & 13 & 5.1 \\
$46-50$ & 7 & 2.7 \\
above 50 & 9 & 3.5 \\
\hline Gender & & \\
Male & 148 & 57.8 \\
Female & 108 & 42.2 \\
\hline Qualification & 10 & 3.9 \\
Intermediate & 89 & 34.8 \\
Bachelor's & 143 & 55.9 \\
MPhil/MS & 14 & 5.5 \\
PHD & & \\
\hline Marital Status & 131 & 51.2 \\
Single & 125 & 48.8 \\
\hline Married & 66 & 66 \\
\hline Position in Organization & 190 & 190 \\
\hline Top-level management & & \\
Middle-level Management & & \\
\hline
\end{tabular}

Table 1 shows that 57.8 percent $(n=148)$ respondents are males and 42.2 percent $(n=108)$ respondents are females. 55.9 percent of respondents have MPhil/MS or above qualification. 74.2 percent $(n=90)$ respondents were working in middle-level management and 25.8 percent $(n=66)$ were working in Toplevel management positions. The measure of perception of individuals regarding authentic leadership was derived from the authentic leadership instrument developed by Neider and Schriesheim (2011). A total of fourteen items have been used to record the perception of respondents regarding various aspects of authentic leadership such as self-awareness (e.g., "My manager shows that he/she understands his/her strengths and weaknesses."), relational transparency (e.g., "My manager openly shares information with others."), internalized moral perspective (e.g., "My manager shows consistency between his/her beliefs and actions."), and balanced processing of the leader (e.g., "My manager carefully listens to alternative perspectives before concluding."). Symmetrical communication was operationalized using six items used by Dozier et al (2013). Sample items included "I am comfortable talking to my manager when things are going wrong;" "Most communication between management and other employees in this organization can be said to be two-way communication." For the perception of individuals regarding organizational trust, six items assessed by (Hon \& Grunig, 1999) were used (e.g., "I'm willing to let my organization make decisions for people like me during the change"). Perception of individuals regarding openness to change four items adapted from (Wanberg \& Banas, 2000) were used (e.g., "I would consider myself open to the changes."). To record the intensity of responses we used the five-point Likert scale.

\section{Data Analysis}

This section outlines the study results, which have been obtained after analyzing the collected data. Initially, SPSS 20 was used to find out the descriptive statistics. In the first part, through descriptive analysis, the results of demographic variables have shown. In the second section, the results of the Path estimation and significance and relationships of dependent, independent, and mediating variables have been demonstrated through bootstrapping. We used Smart-PLS 3.2.9 (Ringle et al., 2015) to analyze 
data.

\section{Assessment of Measurement Model}

In SmartPLS, there are two models. One is the measurement model, and the second is a structural model (Joe F Hair et al., 2011). In the measurement model, there are three important analysis to evaluate the model. One is internal consistency, the second is discriminant validity, and the third is convergent validity (Table 2). Reliability measures the stability and consistency of the data. There are three techniques to assess internal consistency. One is Cronbach's alpha, and the other two are composite reliability and Rho-A (Bacon et al., 1995).

On the other hand, convergent validity measures of constructs should be related to the other criteria (Chin, 2010). There are two factors to measure convergent validity. One is outer loading, and the second is AVE (Chin, 2010; Mela \& Kopalle, 2002), and discriminant validity occurs when two or more variables are anticipated uncorrelated. There are three techniques used for evaluating discriminant validity. One is Crossloadings, and the other two are Fornell and Larcker (1981) and HTMT (Hair Jr et al., 2016).

Table 2 Alpha, rho-A, CR, AVE, Indicator Reliability, Cross Loadings, And VIF

\begin{tabular}{|c|c|c|c|c|c|c|c|c|}
\hline Construct & $\begin{array}{l}\text { Indic- } \\
\text { ator }\end{array}$ & Alpha & rho-A & $\begin{array}{l}\text { Composite } \\
\text { Reliability }\end{array}$ & $\overline{A V E}$ & $\begin{array}{l}\text { Indicator } \\
\text { Reliability }\end{array}$ & $\begin{array}{l}\text { Cross } \\
\text { loadings }\end{array}$ & VIF \\
\hline $\begin{array}{l}\text { Authentic } \\
\text { Leadership } \\
\text { (AL) }\end{array}$ & $\begin{array}{l}\text { AL1 } \\
\text { AL2 } \\
\text { AL3 } \\
\text { AL4 } \\
\text { AL5 } \\
\text { AL6 } \\
\text { AL7 } \\
\text { AL12 } \\
\text { AL13 } \\
\text { AL14 }\end{array}$ & 0.844 & 0.851 & 0.876 & 0.415 & $\begin{array}{l}0.662 \\
0.623 \\
0.609 \\
0.701 \\
0.561 \\
0.604 \\
0.688 \\
0.635 \\
0.726 \\
0.613\end{array}$ & $\begin{array}{l}0.662 \\
0.623 \\
0.609 \\
0.701 \\
0.561 \\
0.604 \\
0.688 \\
0.635 \\
0.726 \\
0.613\end{array}$ & $\begin{array}{l}1.619 \\
1.553 \\
1.457 \\
1.706 \\
1.494 \\
1.539 \\
1.701 \\
1.381 \\
1.616 \\
1.498\end{array}$ \\
\hline $\begin{array}{l}\text { Organizational } \\
\text { Trust }(\mathrm{OT})\end{array}$ & $\begin{array}{l}\text { OT1 } \\
\text { OT2 } \\
\text { OT3 } \\
\text { OT5 } \\
\text { OT6 }\end{array}$ & 0.743 & 0.743 & 0.829 & 0.493 & $\begin{array}{l}0.728 \\
0.707 \\
0.735 \\
0.639 \\
0.699\end{array}$ & $\begin{array}{l}0.728 \\
0.707 \\
0.735 \\
0.639 \\
0.699\end{array}$ & $\begin{array}{l}1.476 \\
1.572 \\
1.550 \\
1.216 \\
1.308\end{array}$ \\
\hline $\begin{array}{l}\text { Openness to } \\
\text { Change (OTC) }\end{array}$ & $\begin{array}{l}\text { OTC1 } \\
\text { OTC2 } \\
\text { OTC3 } \\
\text { OTC4 }\end{array}$ & 0.712 & 0.722 & 0.818 & 0.530 & $\begin{array}{l}0.705 \\
0.724 \\
0.682 \\
0.794\end{array}$ & $\begin{array}{l}0.705 \\
0.724 \\
0.682 \\
0.794\end{array}$ & $\begin{array}{l}1.181 \\
1.447 \\
1.584 \\
1.550\end{array}$ \\
\hline $\begin{array}{l}\text { Symmetrical } \\
\text { Communication } \\
\text { (SC) }\end{array}$ & $\begin{array}{l}\text { SC2 } \\
\text { SC3 } \\
\text { SC4 } \\
\text { SC5 } \\
\text { SC6 }\end{array}$ & 0.690 & 0.719 & 0.798 & 0.445 & $\begin{array}{l}0.576 \\
0.639 \\
0.792 \\
0.648 \\
0.662\end{array}$ & $\begin{array}{l}0.576 \\
0.639 \\
0.792 \\
0.648 \\
0.662\end{array}$ & $\begin{array}{l}1.286 \\
1.505 \\
1.468 \\
1.409 \\
1.392\end{array}$ \\
\hline
\end{tabular}

Indicators AL-8, AL-9, AL10, and AL-11 were removed from authentic leadership because of weak outer loadings. No indicator from openness to change was removed. However, SC-1 was removed from symmetrical communication and OT-4 from the organizational trust due to weak loadings. AVE was observed slightly below the cutoff value, i.e., 0.48, but these values are also acceptable (Malhotra et al., 
2006). The range of cross loading should be greater than +- 0.20. Fornel and Larcker's (1981) criteria are used to measure the degree of shared variance, which is found by taking the under-root of AVE values (Fornell \& Larcker, 1981). HTMT and Fornel and Larcker's (1981) criteria results are shown in Table 2. The value of HTMT should not be greater than 0.9 (Henseler et al., 2015).

\section{Assessment of Structural Model}

A structural model is also called an inner model. The structural model can be assessed through the following basic techniques; Inner VIF, coefficient of determination $\left(\mathrm{R}^{2}\right), \mathrm{F}^{2}, \mathrm{Q}^{2}$, and path significance (Hair et al., 2013). These values are given in Table 3.

These are the parameters to assess the structural model. The value of Inner VIF should not be greater than \pm 5 (Hair et al., 2013). $\mathrm{R}^{2}$ is a statistical measure, which indicates the percentage of variance in the outcome variable due to an independent variable. There are three levels or cases of $\mathrm{R}^{2}$ through which it can be evaluated. First, if the value is 0.75 or close to 0.75 , then the Model is strong. The second is if the value of $\mathrm{R}^{2}$ is 0.50 or close to 0.50 , then it is moderate. Finally, if the value of $\mathrm{R}^{2}$ is 0.25 or close to 0.25 , then the model is weak. In this study, the $\mathrm{R}^{2}$ of OTC is 0.428 , and OT is 0.491 , which is close to 0.50 , which means the Model is moderate.

Table 3 Fornel-Larcker (1981), Coefficient of Determination and $Q^{2}$

\begin{tabular}{|c|c|c|c|c|c|c|c|}
\hline Construct & $\overline{\mathbf{A L}}$ & $\overline{\text { OTC }}$ & $\overline{\text { OT }}$ & SC & $\overline{\mathbf{R}^{2}}$ & $\mathbf{R}^{2}$ Adjusted & $\mathbf{Q}^{2}$ \\
\hline $\begin{array}{l}\text { AL } \\
\text { OTC } \\
\text { OT } \\
\text { SC }\end{array}$ & $\begin{array}{l}\mathbf{0 . 6 6 4} \\
0.503 \\
0.603 \\
0.417\end{array}$ & $\begin{array}{l}\mathbf{0 . 7 2 8} \\
0.630 \\
0.448\end{array}$ & $\begin{array}{l}\mathbf{0 . 7 0 2} \\
0.576\end{array}$ & 0.667 & $\begin{array}{l}- \\
0.428 \\
0.491 \\
-\end{array}$ & $\begin{array}{l}- \\
0.421 \\
0.487 \\
-\end{array}$ & $\begin{array}{l}- \\
0.201 \\
0.231 \\
-\end{array}$ \\
\hline
\end{tabular}

Predictive relevance can be assessed through the $\mathrm{Q}^{2}$ value (Stone, 1974; Geisser, 1975). The value of $\mathrm{Q}^{2}$ should be greater than 0.0. As per criteria, the value of $\mathrm{Q}^{2}$ should be greater than 0.0 , and in this study, the value of $\mathrm{Q}^{2}$ of OTC and OC is 0.201 and 0.231 respectively, which is greater than 0.0 , indicating the predictive relevance of the model.

\section{Discussion and Findings}

Regarding the first objective of this study which is to investigate the relationship between authentic leadership and organizational trust $(\mathrm{H} 1)$ the statistics were significant (beta=.443, $\mathrm{t}=7.132, \mathrm{p}<.05$ ). Empirical evidence indicates that the change in authentic leadership will bring positive change in organizational trust among employees (Coxen et al., 2016). It implies that if a manager adopts an authentic leadership style, the corporate trust of an employee increases.

The second objective of this study was to investigate the impact of symmetrical communication on organizational trust (H2). The statistics were significant (beta=.395, $\mathrm{t}=5.756, \mathrm{p}<.05$ ). Empirical evidence indicates that symmetrical communication will bring positive change in organizational trust among employees. Statistics supported the results, and it has been proved that if the organization uses symmetrical communication, an employee's trust in the organization increases. Table 4 shows the results of the study with regard to the hypotheses acceptance/rejection. 
Table 4 Hypotheses Testing

\begin{tabular}{|c|c|c|c|c|c|}
\hline \multicolumn{2}{|c|}{ Hypotheses } & \multirow{2}{*}{$\begin{array}{l}\text { B } \\
0.443\end{array}$} & \multirow{2}{*}{$\begin{array}{l}\mathbf{T} \\
7.132\end{array}$} & \multirow{2}{*}{$\begin{array}{l}\mathbf{P} \\
0.00\end{array}$} & \multirow{2}{*}{$\begin{array}{l}\text { Status } \\
\text { Supported }\end{array}$} \\
\hline H1 & $\mathrm{AL} \rightarrow \mathrm{OT}$ & & & & \\
\hline $\mathrm{H} 2$ & $\mathrm{SC} \rightarrow \mathrm{OT}$ & 0.395 & 5.756 & 0.00 & Supported \\
\hline H3 & $\mathrm{OT} \rightarrow \mathrm{OC}$ & 0.453 & 6.087 & 0.00 & Supported \\
\hline $\mathrm{H} 4$ & $\mathrm{AL} \rightarrow \mathrm{OC}$ & 0.185 & 2.821 & 0.01 & Supported \\
\hline H5 & $\mathrm{SC} \rightarrow \mathrm{OC}$ & 0.114 & 1.405 & 0.16 & $\begin{array}{l}\text { Not } \\
\text { Supported }\end{array}$ \\
\hline \multicolumn{2}{|c|}{ Hypotheses } & $\begin{array}{l}\text { Indirect } \\
\text { effect }\end{array}$ & Total effect & VAF & Status \\
\hline H6 & $\mathrm{AL} \rightarrow \mathrm{OT} \rightarrow \mathrm{OC}$ & 0.201 & 0.38 & $53 \%$ & Supported \\
\hline H7 & $\mathrm{SC} \rightarrow \mathrm{OT} \rightarrow \mathrm{OC}$ & 0.178 & 0.29 & $61 \%$ & Supported \\
\hline
\end{tabular}

The third objective was to examine the connection between organizational trust and openness to change (H3). Here the results were significant (beta=.453, $\mathrm{t}=6.087, \mathrm{p}<.05$ ). Empirical evidence indicates that the change in the organizational trust will bring positive change in openness to change among employees (Yue et al., 2019). These results confirm that the more employees trust their organization, the more they are ready to accept the change in the organization. Forth objective was to investigate the link between authentic leadership and openness to change $(\mathrm{H} 4)$. The results were significant (beta=.185, $\mathrm{t}=2.821$, $\mathrm{p}<.05)$. Empirical evidence indicates that the change in authentic leadership will bring positive change in openness to change among employees. It can be implied that if the manager adopts an authentic leadership style in the organization, the more employees are ready to accept the change.

The fifth objective was to scrutinize the relationship between symmetrical communication and openness to change (H5). However, the results were insignificant in this case (beta=.114, $\mathrm{t}=1.405, \mathrm{p}>.05$ ). Empirical evidence indicates that the change in symmetrical communication will bring no change in openness to change among employees. The sixth objective was to assess mediating role of organizational trust between the relationship of authentic leadership and openness to change (H6). Calculations were assessed by the VAF (Hair et al., 2012). Bootstrapping makes no assumptions about the shape of the variables' distribution or the sampling distribution of the statistics and can be applied to small sample sizes with more confidence. The approach is therefore perfectly suited for the PLS-SEM method. VAF shows higher levels of statistical power compared with the Sobel test (Hair et al., 2012). The variance accounted for (VAF) determines the size of the indirect effect about the total effect (direct effect+ indirect effect). If VAF is less than twenty percent, there is no mediation, if VAF is greater than twenty percent and less than eighty percent, there is a partial mediation, and VAF is greater than 80 percent, there is full mediation. In our results, the value of VAF was fifty three percent, assuming organizational trust partially mediates the relationship between authentic leadership and openness to change.

The last objective of this study was to assess the mediation impact of organizational trust between the relationship of symmetrical communication and openness to change $(\mathrm{H} 7)$. The value of VAF was sixty one percent, and it can be assumed that organizational trust also partially mediates the relationship between symmetrical communication and openness to change. 


\section{Conclusion}

Findings show that authentic leadership is a strong predictor of openness to change among employees. Authentic leadership brings an increase in employees' susceptibility to change. Organizational trust also positively affects employees' openness to change. On further investigation, it can also be concluded that symmetrical communication strongly impacts organizational trust, which partially mediates the relationship between authentic leadership and openness to change. Empirical results show that authentic leadership can promote trust.

Moreover, this trust brings a perceptional change among employees, and they show a willingness to accept change within organizational circuits. Similarly, symmetrical communication also promotes acceptance to change through organizational trust. Thus developing a perception of trust among individuals within corporate circuits brings positive benefits for both organization and employees. Therefore, organizations need to promote authentic leadership style and symmetrical communication if they introduce change within their organizations because it will build trust. Eventually, employees will show their willingness to accept change.

The study has many theoretical contributions. Firstly, this study extends the existing knowledge on authentic leadership by exploring the mediating role of organizational trust between authentic leadership and employees' openness to change. It adds important insights into the literature. Many studies have discovered the impact of authentic leadership on different variables. However, the link between authentic leadership and employees' openness to change has not been explored yet (Yue et al., 2019). The direct relationship of symmetrical communication and openness to change have not been studied yet. Moreover, the findings of this study also endorse the use of SET. When perceiving an authentic leadership role from their supervisors, employees tend to accept change and behave accordingly.

This research, however, is not without limitations. Firstly, this study is a cross-sectional study, and future research may consider a longitudinal research design. Secondly, this study was bounded in a limited geographical location, and in the future, this study can be replicated in other geographical areas and diverse cultures. Thirdly, in this study, data were collected only from the top and middle-level employees working in manufacturing and service organizations. In the future, data can also be collected from low-level management. This study used quantitative research methods, leaving room for a more detailed understanding of the proposed model through qualitative research methods in the future. Finally, in this study, only authentic leadership is considered a predictor of employees' openness to change. Other leadership styles, such as ethical leadership and servant leadership, can also be examined to impact employees' susceptibility to change.

\section{References}

Alilyyani, B., Wong, C. A., \& Cummings, G. (2018). Antecedents, mediators, and outcomes of authentic leadership in healthcare: A systematic review. International journal of nursing studies, 83, 3464. https://doi.org/10.1016/j.ijnurstu.2018.04.001

Allen, J., Jimmieson, N. L., Bordia, P., \& Irmer, B. E. (2007). Uncertainty during Organizational Change: Managing Perceptions through Communication. Journal of Change Management, 7(2), 187-210.

https://doi.org/10.1080/14697010701563379

Alvesson, M., \& Einola, K. (2019). Warning for excessive positivity: Authentic leadership and other traps in leadership studies. The Leadership Quarterly, 30(4), 383-395.

https://doi.org/10.1016/j.leaqua.2019.04.001

Augustsson, H., Richter, A., Hasson, H., \& von Thiele Schwarz, U. (2017). The Need for Dual Openness to Change: A Longitudinal Study Evaluating the Impact of Employees' Openness to Organizational Change Content and Process on Intervention Outcomes. Journal of Applied Behavioral Science, 53(3), 349-368. https://doi.org/10.1177/0021886317691930

Avolio, B. J., Gardner, W. L., Walumbwa, F. O., Luthans, F., \& May, D. R. (2004). Unlocking the 
mask: A look at the process by which authentic leaders impact follower attitudes and behaviors. Leadership Quarterly, 15(6), 801-823. https://doi.org/10.1016/j.leaqua.2004.09.003

Bacon, D. R., Sauer, P. L., \& Young, M. (1995). Composite reliability in structural equations modeling. Educational and Psychological Measurement, 55(3), 394-406. https://doi.org/10.1556/2006.7.2018.67

Bakari, H., Hunjra, A. I., Jaros, S., \& Khoso, I. (2019). Moderating role of cynicism about organizational change between authentic leadership and commitment to change in Pakistani public sector hospitals. Leadership in Health Services, 32(3), 387-404.

https://doi.org/10.1108/LHS-01-2018-0006

Barclay, D., Higgins, C., \& Thompson, R. (1995). The partial least squares (PLS) approach to causal modeling: personal computer adoption and use as an Illustration. Asian Journal of University Education, 16(3), 220-233. EJ1274172.pdf (ed.gov)

Basit, A., \& Siddiqui, D. A. (2020). Authentic Leadership and Openness to Change in Pakistani Service Industry: The Mediating Role of Trust and Transparent Communication. International Journal of Human Resource Studies, 10, 291-341. https://doi.org/10.5296/ijhrs.v10i3.17318

Blau, P. M. (1964). Justice in social exchange. Sociological Inquiry, 34(2), 193-206. https://doi.org/10.1111/j.1475-682X.1964.tb00583.x

Cameron, K., \& Dutton, J. (2003). Positive organizational scholarship: Foundations of a new discipline. Berrett-Koehler Publishers.

Chawla, A., \& Kevin Kelloway, E. (2004). Predicting openness and commitment to change. Leadership \& Organization Development Journal, 25(6), 485-498. https://doi.org/10.1108/01437730410556734

Chin, W. W. (2010). How to write up and report PLS analyses. In Handbook of partial least squares (pp. 655-690). Springer.

Corley, K. G., \& Gioia, D. A. (2004). Identity ambiguity and change in the wake of a corporate spinoff. Administrative Science Quarterly, 49(2), 173-208. https://doi.org/10.2307/4131471

Coxen, L., van der Vaart, L., \& Stander, M. W. (2016). Authentic leadership and organizational citizenship behavior in the public health care sector: The role of workplace trust. SA Journal of Industrial Psychology, 42(1), 1-13. https://doi.org/10.4102/sajip.v42i1.1364

Currall, S. C., \& Epstein, M. J. (2003). The fragility of organizational trust: Lessons from the rise and fall of Enron. Organizational Dynamics, 32(2), 193-206. https://doi.org/10.1016/S0090-2616(03)00018-4

Dozier, D. M., Grunig, L. A., \& Grunig, J. E. (2013). Manager's guide to excellence in public relations and communication management. Routledge.

Duffy, J., \& Lilly, J. (2013). Do Individual Needs Moderate the Relationships between Organizational Citizenship Behavior, Organizational Trust, and Perceived Organizational Support? Journal of Behavioral and Applied Management, 14(3), 185-197.

Elving, W. J. L. (2005). The role of communication in organizational change. Corporate Communications, 10(2), 129-138. https://doi.org/10.1108/13563280510596943

Ertürk, A. (2008). A trust-based approach to promote employees' openness to organizational change in Turkey. International Journal of Manpower, 29(5), 462-483. https://doi.org/10.1108/01437720810888580

Fornell, C., \& Larcker, D. F. (1981). Evaluating structural equation models with unobservable variables and measurement error. Journal of Marketing Research, 18(1), 39-50. https://doi.org/10.1177\%2F002224378101800104

Geisser, S. (1975). The predictive sample reuse method with applications. Journal of the American Statistical Association, 70(350), 320-328. https://doi.org/10.1080/01621459.1975.10479865

George, Bill, Sims, P., McLean, A. N., \& Mayer, D. (2007). Discovering your authentic leadership. Harvard Business Review, 85(2).

Grau, J. (1994). Antecedents to Willingness to Participate in a Planned Organizational Change. Journal of Applied Communication Research, 22(1), 59-80. https://doi.org/10.1080/00909889409365387

Gray, J., \& Laidlaw, H. (2004). Improving the measurement of communication 
satisfaction. Management

Communication

Quarterly, 17(3),

$425-448$. https://doi.org/10.1177/0893318903257980

Grunig, J. E., \& Grunig, L. A. (2011). Characteristics of excellent communication. The IABC Handbook of Organizational Communication: A Guide to Internal Communication, Public Relations, Marketing, and Leadership, 11(3).

Hair Jr, Joe F, Sarstedt, M., Hopkins, L., \& Kuppelwieser, V. G. (2014). Partial least squares structural equation modeling (PLS-SEM). European Business Review, 26(2), 106-121. https://doi.org/10.1108/EBR-10-2013-0128

Hair Jr, Joseph F, Hult, G. T. M., Ringle, C., \& Sarstedt, M. (2016). A primer on partial least squares structural equation modeling (PLS-SEM). Sage publications.

Hair, Joe F, Ringle, C. M., \& Sarstedt, M. (2011). PLS-SEM: Indeed, a silver bullet. Journal of Marketing Theory and Practice, 19(2), 139-152. https://doi.org/10.2753/MTP1069-6679190202

Hair, Joe F., Sarstedt, M., Ringle, C. M., \& Mena, J. A. (2012). An assessment of the use of partial least squares structural equation modeling in marketing research. Journal of the Academy of Marketing Science, 40(3), 414-433. https://doi.org/10.1007/s11747-011-0261-6

Hair, Joseph F, Ringle, C. M., \& Sarstedt, M. (2013). Partial least squares structural equation modeling: Rigorous applications, better results, and higher acceptance. Long Range Planning, 46(1-2), 112.

Henseler, J., Ringle, C. M., \& Sarstedt, M. (2015). A new criterion for assessing discriminant validity in variance-based structural equation modeling. Journal of the Academy of Marketing Science, 43(1), 115-135. https://doi.org/10.1007/s11747-014-0403-8

Hon, L. C., \& Grunig, J. E. (1999). Guidelines for measuring relationships in public relations. Commission on Public Relations Measurement \& Evaluation, November, 1-40.

Microsoft Word - Guidelines_Measuring_Relationships.doc (painepublishing.com)

Ilyas, M., Muneer, S., \& Tripathi, A. (2020). Analyzing building blocks of organizational trust and openness during change process in Saudi Arabia's telecom sector. Polish Journal of Management Studies, 21(1), 173-185.

Johansson, C., \& Heide, M. (2008). Speaking of change: Three communication approaches in studies of organizational change. Corporate Communications, 13(3), 288-305.

https://doi.org/10.1108/13563280810893661

Kang, M., \& Sung, M. (2017). How symmetrical employee communication leads to employee engagement and positive employee communication behaviors: The mediation of employeeorganization relationships. Journal of Communication Management, 21(1), 82-102. https://doi.org/10.1108/JCOM-04-2016-0026

Kiliç, M. Y., \& Yavuz, M. (2021). The Evaluation of Authentic Leadership in terms of Trust in Manager and Schools' Levels of Openness to Change. Cukurova University Faculty of Education Journal, 50(2), 1033-1068.

Kouzes, J. M., \& Posner, B. Z. (2006). The leadership challenge (Vol. 3). John Wiley \& Sons.

Leroy, H., Palanski, M. E., \& Simons, T. (2012). Authentic Leadership and Behavioral Integrity as Drivers of Follower Commitment and Performance. Journal of Business Ethics, 107(3), 255264. https://doi.org/10.1007/s10551-011-1036-1

Majeed, H., Kayani, U. N., \& Haider, S. A. (2021). The Project Communication and Trust Nexus as an Antecedents of Project Success: Moderating Role of Authentic Leadership. International Journal

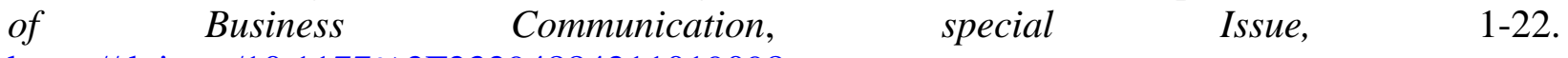
https://doi.org/10.1177\%2F23294884211019098

Malhotra, N. K., Kim, S. S., \& Patil, A. (2006). Common method variance in IS research: A comparison of alternative approaches and a reanalysis of past research. Management Science, 52(12), 18651883. https://doi.org/10.1287/mnsc. 1060.0597

Mela, C. F., \& Kopalle, P. K. (2002). The impact of collinearity on regression analysis: the asymmetric effect of negative and positive correlations. Applied Economics, 34(6), 667-677. https://doi.org/10.1080/00036840110058482

Neider, L. L., \& Schriesheim, C. A. (2011). The Authentic Leadership Inventory (ALI): Development 
and empirical tests. Leadership Quarterly, 22(6), 1146-1164.

https://doi.org/10.1016/j.leaqua.2011.09.008

Nielsen, K., \& Randall, R. (2013). Opening the black box: Presenting a model for evaluating organizational-level interventions. European Journal of Work and Organizational Psychology, 22(5), 601-617. https://doi.org/10.1080/1359432X.2012.690556

Nielsen, K., Randall, R., Holten, A. L., \& González, E. R. (2010). Conducting organizational-level occupational health interventions: What works? Work and Stress, 24(3), 234-259. https://doi.org/10.1080/02678373.2010.515393

Oberoi, R., Halsall, J. P., \& Snowden, M. (2021). Reinventing social entrepreneurship leadership in the COVID-19 era: engaging with the new normal. Entrepreneurship Education, 4(2), 117-136. https://doi.org/10.1007/s41959-021-00051-X

Pawar, B. S., \& Eastman, K. K. (1997). The nature and implications of contextual influences on transformational leadership: A conceptual examination. Academy of management review, 22(1), 80-109. https://doi.org/10.5465/amr.1997.9707180260

Pearse, N. J. (2017). Change management in a VUCA world. In Visionary Leadership in a Turbulent World. Emerald Publishing Limited.

Rawlins, B. R. (2008). Measuring the relationship between organizational transparency and employee trust. Public Relations Journal, 2(2), 1-21. http://hdl.lib.byu.edu/1877/2087

Ringle, C. M., Wende, S., \& Becker, J. M. (2015). SmartPLS 3. Boenningstedt: SmartPLS GmbH.

Rousseau, D. M., \& Tijoriwala, S. A. (1999). What's a good reason to change? Motivated reasoning and social accounts in promoting organizational change. Journal of applied psychology, 84(4), 514528. https://doi.org/https://doi.org/10.1037/0021-9010.84.4.514

Saks, A. M. (2006). Antecedents and consequences of employee engagement. Journal of Managerial Psychology, 21(7), 600-619. https://doi.org/10.1108/02683940610690169

Schoorman, F. D., Mayer, R. C., \& Davis, J. H. (2007). An integrative model of organizational trust: Past, present, and future. Academy of Management review, 32(2), 344-354. https://doi.org/10.5465/amr.2007.24348410

Walumbwa, F. O., Avolio, B. J., Gardner, W. L., Wernsing, T. S., \& Peterson, S. J. (2008). Authentic leadership: Development and validation of a theory-based measure. Journal of Management, 34(1), 89-126. https://doi.org/10.1177/0149206307308913

Wanberg, C. R., \& Banas, J. T. (2000). Predictors and outcomes of openness to changes in a reorganizing workplace. Journal of Applied Psychology, 85(1), 132-142. https://doi.org/10.1037/0021-9010.85.1.132

Whitener, E. M., Brodt, S. E., Korsgaard, M. A., \& Werner, J. M. (1998). Managers as initiators of trust: An exchange relationship framework for understanding managerial trustworthy behavior. Academy of Management Review, 23(3), 513-530. https://doi.org/10.5465/amr.1998.926624

Yang, S. U. (2007). An integrated model for organization-public relational outcomes, organizational reputation, and their antecedents. Journal of Public Relations Research, 19(2), 91-121. https://doi.org/https://doi.org/10.1080/10627260701290612

Yang, Y. F. (2014). Studies of transformational leadership: Evaluating two alternative models of trust and satisfaction. Psychological Reports, 114(3), 740-757. https://doi.org/10.2466/01.04.PR0.114k27w2

Yue, C. A., Men, L. R., \& Ferguson, M. A. (2019). Bridging transformational leadership, transparent communication, and employee openness to change: The mediating role of trust. Public Relations Review, 45(3), 101779. https://doi.org/10.1016/j.pubrev.2019.04.012 